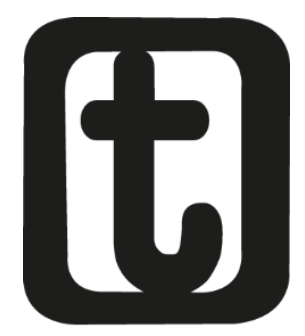

\title{
PROJETO ÉTICO-POLÍTICO, CONSCIÊNCIA DE CLASSE E PROJETO SOCIETÁRIO: UMA RELAÇÃO DIALÉTICA
}

Political-ethical project, class consciousness and social project: $a$ dialectic relationship.

\section{Salyanna de Souza Silva ${ }^{1}$ Maria Alexandra da Silva Monteiro Mustafá}

\section{RESUMO}

Este artigo apresenta os principais resultados da Dissertação realizada junto ao Programa de Pós-Graduação em Serviço Social na Universidade Federal de Pernambuco (UFPE), em 2011. Teve como objetivo principal analisar, a partir da atuação junto aos usuários(as) e da mobilização junto aos demais trabalhadores(as) da assistência social, o movimento da consciência de classe das/dos assistentes sociais dos Centros de Referência da Assistência Social

\footnotetext{
${ }^{1}$ Mestrado em Serviço Social pela Universidade Federal de Pernambuco (2011). Assistente Social da Secretaria de Assistência Social, Prefeitura da Cidade de Recife. E-mail: <salyanna@ig.com.br>.

${ }^{2}$ Mestrado em Serviço Social pela Universidade Federal de Pernambuco (1992). Doutorado em Filosofia pela Università Pontificia Salesiana de Roma (1999). Professora Adjunto I da Universidade Federal de Pernambuco. E-mail: <alexandramustafa@ig.com.br>
} 


\section{temporalis}

SILVA, S. de S.; MUSTAFÁ, M. A. da S. M. PROJETO ÉTICO-POLÍTICO

(CRASs) de Recife; e sua relação dialética com o Projeto ÉticoPolítico. A efetivação do projeto profissional do Serviço Social é tensionada por diversos fatores, sendo necessária a construção democrática de espaços coletivos juntamente a outras categorias profissionais e movimentos sociais. Nesse processo entendemos como componente essencial o reconhecimento de pertencimento à classe trabalhadora, por meio da tomada de consciência classe. Em nossas reflexões percebemos que as/os assistentes sociais dos CRASs em Recife, como também os demais trabalhadores(as) da Assistência Social, passam por um processo de uma tomada de consciência enquanto grupo, com indícios de identidade e solidariedade entre seus membros. Tal movimento contribui para a organização e fortalecimento desse segmento, visando, além da garantia dos direitos trabalhistas, a melhor implementação da política de assistência social no município. Ressaltamos que esse processo é a constatação de que existe um forte indício de objetivação do projeto profissional em uma interlocução com a construção de um novo projeto societário para a sociedade brasileira.

\section{PALAVRAS-CHAVE}

Política de Assistência Social. Consciência de classe. Projeto profissional.

\section{ABSTRACT}

This article presents the main results of the dissertation carried out at the Postgraduate Program in Social Work at the Federal University of Pernambuco (UFPE) in 2011. It aims at analyzing, based on interaction with social care service users and the mobilization with other social care workers, the movement of class consciousness of social workers at Reference Centers for Social Welfare (CRASs) in Recife, and its dialectical relationship with the ethical-political project. The realization of the social work professional project is strained by several factors. Therefore, the 


\section{tempordilis}

SILVA, S. de S.; MUSTAFÁ, M. A. da S. M. PROJETO ÉTICO-POLÍTICO

need of constructing democratic collective spaces, as well as other professional groups and social movements. In this process, we understand the sense of belonging to the working class - class consciousness - as an essential component. In our reflections we see that the CRAS social workers in Recife, as well as other employees of Social Welfare, undergo a consciousness-raising process as a group, with evidence of identity and solidarity among its members. This movement helps organize and strengthen this segment, aiming at the ensuring labor rights, as well as better implementing social welfare policy in the municipality. We emphasize that this process verifies the existence of strong indication of objectification of the professional project in $a$ dialogue with the construction of a new social project for Brazilian society.

\section{KEYWORDS}

Social Assistance Policy.Class consciousness.Professional project.

Submetido em 30/04/2011

Aceito em 29/06/2011

\section{INTRODUÇÃO}

Este trabalho se constitui a síntese da Dissertação de Mestrado $^{3}$ e tem como objetivo socializar as conclusões que se traduzem na constatação de que o processo de formação de uma consciência de classe, no interior da categoria profissional de Serviço Social, é um fenômeno presente que nos permite afirmar que o Projeto ÉticoPolítico Profissional (PEP) tem indícios fortes de objetivação, em

\footnotetext{
${ }^{3}$ A dissertação intitulada Projeto Ético-Político e consciência de classe: uma relação dialética. Reflexões sobre o exercício profissional/político das/dos assistentes sociais dos Centros de Referência de Assistência Social (CRAS) em Recife de autoria de Salyanna de Souza Silva e foi realizada no Programa de Pós-Graduação em Serviço Social da Universidade Federal de Pernambuco (UFPE), em 2011, sob orientação de Maria Alexandra da Silva Monteiro Mustafá.
} 
consonância com a interface que se gesta com o Projeto Societário, considerando-se que na atualidade a sociedade civil vem demonstrando uma atitude de resistência e de organização que revela um nível de insatisfação e uma perspectiva propositiva de enfrentamento das expressões da questão social. Nesse sentido, vale ressaltar o terreno fértil na mobilização de diversas categorias profissionais que ganham expressividade em suas reivindicações, não apenas corporativas e de cunho econômico salarial, mas de uma amplitude política, no sentido de fazer valer os direitos civis, políticos e sociais conquistados com o processo de redemocratização (Constituição de 1988), articulando demandas e segmentos os mais amplos nos chamados movimentos sociais de lutas por uma nova ordem societária.

Em nosso estudo, identificamos que a socialização das demandas e da concepção de direito embasada nos princípios do PEP, motivada pelas(os) assistentes sociais, bem como a vivência de condições objetivas comuns conduzem a um envolvimento coletivo de profissionais de outras categorias na mobilização pelas questões trabalhistas, pelas condições de trabalho e pela defesa dos direitos dos usuários que se constituiu uma expressão do desenvolvimento da consciência de classe nos Centros de Referência de Assistência Social (CRAS) ${ }^{4}$ das seis Regiões Político-Administrativas (RPAs) ${ }^{5}$ do município de Recife - objeto de estudo de nossa pesquisa.

O estudo se desenvolveu enquanto aprofundamento da literatura que contém categorias atuais e que fazem parte da produção de conhecimento em Serviço Social, tais como consciência de classe,

\footnotetext{
${ }^{4}$ No decurso deste artigo teceremos maiores considerações esclarecedoras sobre o papel dos CRASs na atual Política de Assistência, assim como enquanto locus da pesquisa aqui apresentada.

5 Regiões Político-Administrativas - distribuição geográfica e política do município de Recife, adotada para a gestão pela Prefeitura da Cidade do Recife.
} 


\section{tempordilis}

SILVA, S. de S.; MUSTAFÁ, M. A. da S. M. PROJETO ÉTICO-POLÍTICO

Política de Assistência Social, Projeto Ético-Político e Projeto Societário, a partir do suporte teórico-prático das disciplinas ofertadas pelo Programa e da pesquisa bibliográfica, documental e de campo, que realizamos no período de 2009 a 2010.

Assim, buscamos analisar a relação dialética entre a materialização do Projeto Ético-Político das/dos assistentes sociais dos CRAS em Recife, a tomada de consciência de classe por parte desses sujeitos e a perspectiva de identificação e formação de um novo Projeto Societário emergente na classe trabalhadora brasileira.

Partindo de um processo de sucessivas aproximações ao real, sentimos a necessidade de acrescentar à discussão sobre o PEP reflexões acerca da tomada de consciência de classe, tendo em vista a atualidade dessa temática em consonância com a constatação de uma carência de estudos mais específicos a respeito desse tema na bibliografia mais recente do Serviço Social ${ }^{6}$.

Nossa pesquisa partiu de um estudo bibliográfico no campo da filosofia, da sociologia e do Serviço Social, enfocando conteúdos da ética e da ontologia do ser social que nos remetem necessariamente à abordagem sobre a consciência de classe. Quanto à Política de Assistência Social, considerando suas reconfigurações na conjuntura atual, fizemos uma leitura de documentos oficiais, tanto nacionais quanto do município de Recife, tais como Política Nacional de Assistência Social (PNAS) (BRASIL, 2005),Norma Operacional Básica do Sistema Único de

\footnotetext{
${ }^{6}$ Em nossa pesquisa, encontramos abordagens sobre consciência de classe em dissertações de Mestrado em Serviço Social, tais como aquela de autoria da Profa. orientadora deste trabalho, intitulada Ação Católica Operária: Fé e luta em tempos difíceis no Nordeste do Brasil, datada de 1992 e que trata da influência da teologia da libertação no processo de formação de uma consciência de classe entre os militantes da Ação Católica Operária (MUSTAFÁ, 1992).
} 


\section{temporalis}

SILVA, S. de S.; MUSTAFÁ, M. A. da S. M. PROJETO ÉTICO-POLÍTICO

Assistência Social (NOB/SUAS) (BRASIL, 2005), Norma Operacional Básica de Recursos Humanos (NOB-RH/SUAS -2007)(BRASIL, 2007), Plano Decenal SUAS (Plano 10), dentre outros, como também parâmetros e documentos elaborados pelos conselhos federal e regional de Serviço Social (CFESS/CRESS).

O instrumental metodológico do estudo incluiu também a realização de entrevistas semiestruturadas com assistentes sociais dos CRASs, com seis profissionais (uma por equipamento). A coleta de dados incluiu também a consulta a documentos, tais como Plano Municipal de Assistência Social, Plano Plurianual 2010-2013, Anais da VII Conferência Municipal da Assistência Social (2009), Relatório de Atividades das equipes CRAS/GRAS-2009, e o recurso à técnica de observação participante que nos permitiu obter dados quantitativos/qualitativos referentes às atividades realizadas pelas equipes.

Tanto para a observação participante quanto para as entrevistas, os indicadores de que existe uma tomada de consciência de classe por parte das(os) assistentes sociais são os seguintes: participação nas mobilizações da categoria das(os) trabalhadoras(es) da assistência social em assembleias, reuniões, comissões, etc.; discurso e postura politizada sobre suas reivindicações e aquelas dos usuários; e passagem de uma concepção individualista para uma visão coletiva, isto é, da dimensão da singularidade para uma de genericidade, na medida em que se supera o imediatismo das reivindicações para uma postura universalizada.

Por se tratar de uma pesquisa que envolve diretamente seres humanos, sentimos a necessidade de submetê-la ao Comitê de Ética em Pesquisa (CEP) da Universidade Federal de Pernambuco. Após a entrega do relatório final obtivemos a aprovação do referido comitê. 


\section{temporalis}

SILVA, S. de S.; MUSTAFÁ, M. A. da S. M. PROJETO ÉTICO-POLÍTICO

Coerentes com as categorias abordadas e com nossa postura teórico-prática, adotamos como referencial teórico o método materialista histórico-dialético, por compreendermos que este nos possibilita apreender o real para além de sua apresentação imediata/fenomênica.

\section{POLÍTICA DE ASSISTÊNCIA SOCIAL EM RECIFE: ESPAÇO CONTRADITÓRIO DE LUTA}

Partimos do pressuposto de que as políticas sociais são, em principio, respostas negociadas pelo Estado e pelo capital às reivindicações da classe trabalhadora, posto que, da mesma forma que garantem benefícios a essa classe, contraditoriamente contribuem para a reprodução física e ideológica do capital.

A formação social, histórica, política e econômica brasileira, caracterizada principalmente pela subordinação ao capitalismo mundial, imprime às políticas sociais uma subalternidade aos setores mais conservadores da burguesia nacional. Por não possuir uma tradição democrática e laica, a instituição pública do Estado tende a beneficiar os interesses privados e a filantropia.

Outra particularidade das ações governamentais brasileiras é a presença marcante do caráter, ao mesmo tempo, repressor e assistencial (SPOSATI, 2008), ambos objetivando a manutenção de determinados grupos no poder. Tal marca cultural e histórica persiste nos dias atuais, principalmente no que se refere à política de assistência social, que, embora seja reconhecida enquanto direito nos documentos constitucionais, efetivamente não ocupa o mesmo patamar das demais políticas. 


\section{temporalis}

SILVA, S. de S.; MUSTAFÁ, M. A. da S. M. PROJETO ÉTICO-POLÍTICO

As classes subalternas no Brasil têm sua história assinalada pela reivindicação e luta pela democracia e melhores condições de vida. Dessa forma, as três últimas décadas do século XX se constituíram palco de mobilizações e lutas dos mais variados segmentos da sociedade civil organizada (movimentos sociais e setores progressistas) contra a ditadura militar, pela consolidação de uma democracia política, social e econômica, através da conquista de direitos sociais, políticos e civis, que tiveram como marco a elaboração da oitava Constituição Brasileira (1988). Essa foi “[...] uma grande arena de disputas e de esperança de mudanças para os trabalhadores brasileiros" (BEHRING, 2003, p.142).

Assim, após a Constituição de 88, a escolha direta, por parte da população, de seus representantes políticos legítimos, transformou-se num alvo e sinal de possibilidade de materialização de um Projeto Societário que animava os anseios dos segmentos mais progressistas da sociedade brasileira, desde a década de 60. No entanto, já na década de 90, o então eleito Presidente da República, Collor de Mello, inicia um processo de privatizações, redução dos gastos públicos com as políticas sociais, o que representa a adoção do chamado Neoliberalismo. Seu projeto de reestruturação do Estado dá continuidade ao conservadorismo reinante no cenário nacional antes da Constituição, demonstrandose, mais uma vez, a aliança do capital nacional com os interesses de organismos internacionais e multilaterais, tais como o Fundo Monetário Internacional (FMI) e o Banco Mundial.

O governo posterior, Fernando Henrique Cardoso (FHC), consolida a adesão à direção neoliberal, em conformidade com a situação do Brasil na divisão internacional do trabalho. Essa situação é inerente à própria lógica do capital no tocante a sua reprodução a partir da relação que se estabelece entre os países centrais e periféricos, 


\section{tempordilis}

SILVA, S. de S.; MUSTAFÁ, M. A. da S. M. PROJETO ÉTICO-POLÍTICO

isto é, tal como afirma Oliveira (2003), trata-se do mecanismo de um "[...] desenvolvimento desigual e combinado".

Nesse momento, inicia-se a chamada Reforma do Estado, caracterizando-se como uma verdadeira contrarreforma" (BEHRING, 2003) para as políticas sociais, com forte ataque aos direitos sociais garantidos na Constituição, flexibilização das leis trabalhistas, aumento do desemprego e continuidade das privatizações.

Com a vitória de um Partido historicamente de esquerda nos anos 2000 - o Partido dos Trabalhadores (PT) -, o Presidente eleito, Luiz Inácio Lula da Silva, intensifica, contraditoriamente, a proposta de seus antecessores ${ }^{7}$. Contudo, tal governo adota, como direção central, ações voltadas prioritariamente para o programa de transferência de renda no âmbito dosocial, mesmo que o social não seja a prioridade na divisão orçamentária que privilegia a defesa dos interesses do capital, haja vista as medidas adotadas para o enfrentamento de sua crise financeira, criando estratégias para o aumento do consumo e financiamento do setor privado, com a finalidade de evitar a sua falência.

A atenção dada à política social consiste, a nosso ver, numa estratégia de legitimação face à classe trabalhadora, no sentido de implementar uma “[...] justiça como equidade [...]"teoria do

7 Essa contraditoriedade entre atendimento aos requisitos neoliberais dos organismos internacionais e a adoção de medidas de regulamentação da Política de Assistência Social em nível interno constitui por si só tema de pesquisa direcionada para analisar tal objeto de estudo, o que não se constitui objetivo deste artigo. Todavia, vale ressaltar que do ponto de vista jurídico-legal houve um avanço no que se refere à regulamentação da Política de Assistência Social e da implementação do Sistema Único da Assistência Social, fato inédito nos governos que o antecederam. 


\section{temporalis}

SILVA, S. de S.; MUSTAFÁ, M. A. da S. M. PROJETO ÉTICO-POLÍTICO

neoliberal John Rawls (1997), que preconiza uma ascensão dos "[...] menos avantajados [...]" sem tocar na distribuição da riqueza acumulada pelas classes dominantes. Daí o destaque para o Programa Bolsa-Família e a regulamentação da Política de Assistência Social.

O referido direcionamento do governo Lula se dá principalmente com a aprovação das regulamentações referentes à assistência social: em 2004 é aprovada a segunda política de assistência social - Política Nacional de Assistência Social (PNAS-2004), que traz como grande diferencial a instituição do Sistema Único de Assistência Social (SUAS) ${ }^{8}$. Assume destaque a diferenciação entre a Proteção Social Básica, que possui um caráter preventivo, e institui os Centros de Referências de Assistência Social (CRASs) ${ }^{9}$ e a

${ }^{8}$ Com relaçãoà execução orçamentária, a Política da Assistência Social encontra diversos entraves para sua implementação. O Fundo Nacional da Assistência Social, instituído somente em 2006, tem a grande maioria de seus recursos destinados a benefícios de transferência de renda: o Benefício de Prestação Continuada (BPC), a Renda Mensal Vitalícia (RMV). Logo, os recursos para outras ações são sacrificados "O SUAS corre sério risco, se não tiver aporte de orçamento suficiente para serviços, de se tornar apenas uma 'carta de intenção', indicando que, de fato, a opção da política de assistência social não é estruturação de serviços, ou de uma rede de proteção socioassistencial que requer aportes consideráveis de investimento para garantir uma cobertura universal. O caminho escolhido pelo governo é o da focalização com o BolsaFamília, carro-chefe das ações de política de assistência social" (SALVADOR, 2010, p. 350).

${ }^{9} \mathrm{O}$ CRAS é uma unidade pública estatal de base territorial e descentralizada. Conforme a PNAS/2004 deve atender a um total de até 1.000 famílias/ano e referenciar 5.000. É a porta de entrada da política de assistência, possuindo o papel de prestar informações e orientação para a população e de articular com a rede de proteção local, realizar o mapeamento e a organização da rede socioassistencial de proteção básica e promover a inserção das famílias nas demais políticas públicas. Dessa forma, os CRASs devem atender 


\section{tempordilis}

SILVA, S. de S.; MUSTAFÁ, M. A. da S. M. PROJETO ÉTICO-POLÍTICO

Proteção Social Especial, que deve atuar com indivíduos/famílias com direitos destituídos, com enfoque nos Centros de Referência Especializados da Assistência Social (CREAS).

Outra inovação trazida pela Política de Assistência, em suas diferentes regulamentações é o reconhecimento da importância de seus/suas trabalhadores(as) para a garantia da qualidade do serviço prestado, primando pela realização de concurso público para suprir o quadro funcional ${ }^{10}$.

Ao dar ênfase à descentralização das ações, sem perder de vista o comando único, a PNAS-2004 vem trazer a importância da concretização da municipalização para sua implementação. Assim, após a aprovação dessa política cada município remodelou suas ações e órgãos para se inserir no SUAS.

Em Recife, no ano de 2001, é criada a Secretaria da Política de Assistência Social (SPAS), em substituição à Secretaria de Políticas Sociais. A SPAS se transformará na Secretaria de Assistência Social (SAS); esta é responsável pela execução da Proteção Social Básica e Especial (média complexidade) no município.

Houve também a redefinição do papel da Legião Assistencial do Recife - LAR ${ }^{11}$, culminando na sua extinção em 2003 e a consequente criação do Instituto de Assistência Social e Cidadania

fundamentalmente dois grande eixos estruturantes do SUAS, a saber: a matricialidade sociofamiliar e a territorialização.

${ }^{10}$ Ressaltamos aqui que a aprovação de toda regulamentação da assistência social é fruto de reivindicações de diversos setores da sociedade civil, em especial pesquisadores(as) e trabalhadores(as) da área, dentre eles(as) profissionais de Serviço Social.

${ }^{11}$ Instituição sem fins lucrativos, fundada em 1972, que ficava sob coordenação das primeiras-damas, com caráter meramente caritativo.

Temporalis, Brasilia (DF), ano 11, n.21, p.177-209, jan./jun. 2011. 


\section{temporalis}

SILVA, S. de S.; MUSTAFÁ, M. A. da S. M. PROJETO ÉTICO-POLÍTICO

(IASC), uma autarquia vinculada à SAS, com personalidade jurídica de direito público, responsável pelo desenvolvimento de ações e serviços direcionados ao resgate de direitos da população em maior grau de exclusão e vulnerabilidade social, com vínculos familiares fragilizados e/ou rompidos. Na atual configuração da PNAS-2004, o IASC executa os serviços e programas da Proteção Social Especial - Alta Complexidade.

Sob orientação da PNAS-2004, Recife inicia, no ano seguinte, o processo de implantação de 12 (doze) Centros de Referência de Assistência Social (CRASs). Até o momento esse número permanece o mesmo ${ }^{12}$. O município possui apenas um CREAS, que foi implantado em março de 2010. Muitas das ações da proteção especial (alta e média complexidade) continuam sendorealizadas pelo IASC.

A Secretaria de Assistência Social (SAS) da Prefeitura da Cidade do Recife (PCR) tem em seu desenho organizacional a Diretoria de Proteção Social Básica (DPSB); ligada a esta estão as Gerências Regionais de Assistência Social (GRASs), que têm a finalidade de coordenar e articular ações da Proteção Social Básica nos territórios, voltadas à população destinatária da assistência social. Acompanhando os serviços ofertados nos CRASs, as GRAS possuem também uma equipe psicossocial com a finalidade de atender, de forma pontual, à população que reside nos bairros que não possuem CRASs, o que, no modelo adotado pela SAS, significa a grande maioria dos bairros.

\footnotetext{
${ }^{12}$ É importante observar que o Plano Municipal de Assistência Social (2007-2015) da Prefeitura da Cidade do Recife não prevê o aumento do número de CRAS na capital, apenas estabelece como meta adequação da estrutura física e padronização da identidade visual dos equipamentos (RECIFE, 2007) . Contudo, o Plano Plurianual (2010-2013) prevê recursos para um total de 18 (dezoito) CRASs.
} 


\section{tempordilis}

SILVA, S. de S.; MUSTAFÁ, M. A. da S. M. PROJETO ÉTICO-POLÍTICO

Como esse modelo não está presente na PNAS-2004, todos os programas e serviços federais que têm os recursos repassados somente para os territórios que possuem CRASs não chegam à grande maioria dos bairros de Recife, o que exclui dos benefícios e programas as famílias que neles residem.

Fica claro, a partir o exemplo do referido município, que a implementação do SUAS se dá no âmbito de várias dificuldades no que se refere à estruturação desse sistema, sendo evidentesimprovisos e adaptações. O que denota dificuldades de "superação da prevalência de uma cultura política atrasada que historicamente tem associado a Assistência Social a uma prática não institucional"(ARAÚJO; LIMA; SILVA, 2010, p.90).

Em relação aos trabalhadores(as) do SUAS, o município realizou concurso público em 2006 e 2007, respectivamente para SAS ${ }^{13}$ e IASC. Tal iniciativa representa uma conquista, posto que a assistência social possua historicamente uma marca que a caracteriza como nãopolítica. Todavia, essa conquista tem seus impasses, pois assistimos a um intenso processo de pauperização das(dos) trabalhadoras(es) concursadas(os), assim como a precarização das condições de trabalho (oferta inadequada dos serviços), e na não garantia dos direitos trabalhistas (isonomia

\footnotetext{
${ }^{13}$ Tal concurso foi realizado em 2007, para o preenchimento de 229 vagas, sendo 126 (cento e vinte e seis) vagas de Nível Superior e 103 (cento e três) vagas de Nível Médio, carga horária de 30 horas semanais (Edital publicado no Diário Oficial do Município $n^{\circ} .50$ de 5 de maio de 2007). As vagas para nível superior foram para Técnico em Assistência Social 1 (Assistente Social) - 55 vagas; Técnico em Assistência Social 2 (Psicólogo) - 37 vagas; Técnico em Assistência Social 3 (Pedagogo) - 20 vagas; Técnico em Assistência Social 4 (Sociólogo) - 14 vagas.
} 


\section{temporalis}

SILVA, S. de S.; MUSTAFÁ, M. A. da S. M. PROJETO ÉTICO-POLÍTICO

salarial, plano de cargos e carreira, manutenção do poder aquisitivo, etc.).

Dessa forma, podemos afirmar que a política de assistência social em Recife sofre com a total falta de prioridade política e administrativa por parte da PCR/SAS e do Estado, deixando a população quase que totalmente desassistida. Essa política se caracteriza por uma espécie de invisibilidade, acentuada pela sua não descentralização, nos equipamentos que, de acordo com o que preconiza o SUAS, deveriam privilegiar a proteção básica (CRAS).

As condições de trabalho, instalações físicas e estruturais da SAS encontram-se precárias, embora o Plano Municipal de Assistência Social (2007-2015) da PCR estabeleça a adequação física dos CRASs para os anos de 2007/2009.

Assim, o repasse escasso, ou inadequado, para execução da Política da Assistência Social e a desorganização no que diz respeito aos programas, serviços e projetos oferecidos por essa política municipal somam-se às reivindicações trabalhistas, como baixos salários, falta de um Plano de Cargos, Carreiras e Salário e isonomia salarial entre as/os profissionais que exercem as mesmas atribuições daqueles que trabalham nas secretarias da $P C R^{14}$.

\footnotetext{
${ }^{14} \mathrm{Em}$ 2008, a Secretaria de Planejamento Participativo, Obras e Desenvolvimento Urbano e Ambiental da Prefeitura da Cidade do Recife (PCR) realizou concurso público para selecionar candidatos para o preenchimento de 419 vagas, sendo 152 para nível superior. Dentre os cargos previstos no Edital de seleção para nível superior estavam os cargos: Analista de Desenvolvimento Ambiental - Serviço Social (02 vagas) e Analista de Defesa Civil - Serviço Social (35 vagas), com remuneração no valor de $\mathrm{R} \$ 1.900,00$. O Edital para a SAS e IASC, em 2007 e 2006, respectivamente, criam o cargo Técnico da Assistência Social 1 Assistente Social com uma remuneração no valor de $\mathrm{R} \$ 1050,00$. Em ambos os
} 


\section{tempordilis}

SILVA, S. de S.; MUSTAFÁ, M. A. da S. M. PROJETO ÉTICO-POLÍTICO

Tais situações, além de comprometerem a descentralização e efetivação dessa política, prejudicam e fragilizam o exercício das/dos profissionais. Daí ser bastante visível uma permanente rotatividade. Dados apresentados pela SAS revelam que há um déficit de equipes de nível superior nos CRAS de aproximadamente $37,5 \%$ e de $68,8 \%$ de nível médio, perfazendo uma média de 53,2\% de profissionais (dados de dezembro de 2010).

Toda essa situação concreta e real tem impulsionado uma parcela desses profissionais a discutirem e se organizarem, tendo como objetivo reivindicar tanto melhores condições de trabalho quanto uma melhor efetivação da Política de Assistência no município.

Destarte, identificamos constantes mobilizações dessas(es) profissionais concursadas(os) pela consolidação da política e valorização profissional, ocorrendo em diversos espaços e instâncias, e destacamos: 1) Deflagração e participação nas greves (como exemplo temos as greves que ocorreram nos primeiros meses dos anos de 2008 a 2010); 2) Participação nas PréConferências e VII Conferência Municipal da Assistência Social (2009), como também na VII Conferência Nacional, no mesmo ano; 3) Realização de reuniões das equipes para fins de discussão das reivindicações e processo de mobilização.

Acreditamos que essas mobilizações por parte das(dos) trabalhadoras(es) da assistência social, como também dos demais

concursos, para admissão nos referidos cargos um dos requisitos é o título de Bacharel em Serviço Social e registro no Conselho Profissional. As atribuições de cada cargo, previsto nos respectivos editais, são semelhantes, cabendo, nesse caso, isonomia de vencimentos, de acordo com a Lei 17.420 de 24 de janeiro de 2006 - Lei Orgânica do município do Recife, art. 76, § $1^{\circ}$ (RECIFE,1990). 
SILVA, S. de S.; MUSTAFÁ, M. A. da S. M. PROJETO ÉTICO-POLÍTICO

setores da sociedade, possuem um forte viés classista, pois pressionam o poder municipal para que haja o reconhecimento e a visibilidade da assistência social como política pública que deve ser ofertada de forma qualificada aos setores mais pauperizados da sociedade, objetivando, além da melhoria das condições de sobrevivência, a conscientização para a reivindicação de direitos adquiridos, através da criação de espaços de discussão e reflexão. Tal mobilização também faz alusão à luta de classes por se tratar de uma reivindicação trabalhista, em tempos de contrarreforma do Estado.

\section{O EXERCÍCIO PROFISSIONAL/POLÍTICO DAS/DOS ASSISTENTES SOCIAIS NOS CRAS EM RECIFE}

O Serviço Social enquanto profissão inserida na divisão sociotécnica do trabalho (IAMAMOTO, 2003)é compreendido no processo de reprodução das relações sociais capitalistas ${ }^{15}$ e contraditoriamente na sua negação, na medida em que tem como direção da formação e do exercício profissional um Projeto ÉticoPolítico que aponta para a transformação dessa ordem societária. Atualmente o número de Assistentes Sociais, com registros inscritos e ativos nos respectivos CRESS, gira em torno de 95.000 em todo o país (TRABALHAR...,2010).

Regulamentada como liberal, a profissão do Serviço Social dispõe de uma relativa autonomia na condução do exercício profissional e possui um estatuto próprio (Código de Ética, Lei de Regulamentação, etc.). Iamamoto (2008) lembra, contudo, que tal

\footnotetext{
${ }^{15}$ Iamamoto (2003) coloca que a reprodução das relações sociais não se limita à reprodução da força viva do trabalho e dos meios objetivos de produção, mas envolve também a reprodução da produção espiritual do modo de vida capitalista - é o que a autora chama de formas de consciência social.
} 


\section{tempordilis}

SILVA, S. de S.; MUSTAFÁ, M. A. da S. M. PROJETO ÉTICO-POLÍTICO

autonomia é tensionada pela compra e venda da força de trabalho especializada a diferentes empregadores.

Enquanto trabalhador(a) assalariado(a), mediado(a) pelo mercado, o/a assistente social tem a compra e venda de sua força de trabalho intermediada pelo dinheiro/salário. Nesse sentido, a/o assistente social em seu exercício passa por dilemas próprios de sua condição de assalariamento. Dentre esses, lamamoto (2008) destaca a alienação ${ }^{16}$, a precarização das relações trabalhistas e do próprio local de atuação, principalmente na esfera pública ${ }^{17}$.

Contudo, essa relação de compra e venda não subordina a profissão aos interesses exclusivos dos compradores de sua força de trabalho. A relativa autonomia dá a possibilidade de a profissão construir um projeto profissional coletivo, que acompanhe as lutas sociais travadas pelas classes sociais.

A condição de pertencimento a uma classe social não é uma questão subjetiva, de escolha individual/pessoal, mas uma determinação social, histórica e econômica. Dessa forma o Projeto Ético-Político expressa o processo de reconhecimento das/dos

\footnotetext{
${ }^{16}$ Entendemos aqui como alienação a fragmentação do processo de trabalho que separa suas fases de ideação (projeção), execução e controle dos resultados, ou seja, do produto do trabalho que em última instância se transforma em algo alheio e estranho ao(à) trabalhador(a). "Na determinação de que o trabalhador se relaciona com o produto de seu trabalho como [com] um objeto estranho estão todas estas conseqüências. Com efeito, segundo este pressuposto está claro: quanto mais o trabalhador se desgasta trabalhando, tanto mais poderoso se torna o mundo objetivo, alheio que ele cria diante de si, tanto mais pobre se torna ele mesmo, seu mundo interior, [e] tanto menos [o trabalhador] pertence a si próprio" (MARX, 2004, p. 81).

${ }^{17}$ Em nível nacional, 78,16\% das/dos assistentes sociaisestão inseridas/os na esfera pública estatal (CONSELHO..., 2005).
} 
SILVA, S. de S.; MUSTAFÁ, M. A. da S. M. PROJETO ÉTICO-POLÍTICO

assistentes sociais à classe trabalhadora, pressuposto esse comprovado no próprio real.

O Projeto Ético-Político profissional do Serviço Social possui um claro vínculo com um projeto que aponta para a construção de outra sociedade, daí a ênfase em sua dimensão ética e política. Tal direcionamento aponta para a defesa estratégica dos direitos sociais como mediação para a emancipação humana, o que contribui para a formação de uma consciência de classe ${ }^{18}$.

Contudo, esse projeto profissional possui como maior desafio a sua objetivação no cotidiano profissional das/dos assistentes sociais. Pautado nas reflexões em torno dessa temática, afirmamos que diversos determinantes e mediações influenciam nesse processo determinantes relativos tanto às condições materiais de reprodução da força de trabalho das/dos profissionais, ou seja, as relações trabalhistas, quanto a aspectos ligados à consciência classista dos mesmos.

A atual configuração da Política da Assistência Social e sua execução no município de Recife, como vimos anteriormente, afeta diretamente o exercício profissional da/do assistente social. Em face de uma realidade de imensa pauperização e precarização das condições de trabalho, déficit do número de profissionais e de

${ }^{18}$ Em seus estudos e escritos da juventude, Marx (2009a) já apontava para os limites da emancipação política. O autor reconhece que dentro da ordem do capital a conquista de direitos representa um grande progresso, "[...] ela não é, decerto, a última forma da emancipação humana [...], mas é a última forma da emancipação política no interior da ordem mundial" (MARX, 2009a, p.52). Portanto, para ele, somente quando o ser humano reconhecer e organizar-se por suas próprias forças políticas é que estará consumada a emancipação humana. 


\section{tempordilis}

SILVA, S. de S.; MUSTAFÁ, M. A. da S. M. PROJETO ÉTICO-POLÍTICO

equipamentos sociais, baixos salários, etc., encontramos uma pluralidade de ações e práticas profissionais, destacando-se as posturas críticas em defesa da melhor efetivação da política da assistência social, como também posturas que denotam certo grau de fragilidade e fatalismo, frente aos grandes desafios com o qual a/o profissional se depara cotidianamente. Daí o enorme número de exonerações e insatisfação no exercício da profissão.

No que se refere às posturas políticas e críticas por parte das/dos assistentes sociais dos CRASs, observamos que estas(es) procuram se articular e construir posicionamentos coletivos dentro das próprias equipes e junto aos demais profissionais, a fim de se fortalecerem profissional, política e tecnicamente.

A partir dos relatos das/dos profissionais, fica evidente uma clara consciência crítica, sendo esta caracterizada por uma capacidade de interpretar a realidade com suas contradições, numa perspectiva de totalidade, fundamentada em princípios teóricometodológicos e políticos, pautados na teoria crítica e nos fundamentos do método materialista histórico dialético, que se constitui na direção hegemônica da formação do exercício profissional do Serviço Social na atualidade.

Nosso objeto de estudo não se limita à identificação de uma consciência crítica, por entendermos que a consciência de classe tem uma dimensão mais ampla que implica, além da interpretação crítica da realidade, um posicionamento e atuação propositiva no sentido da organicidade ético-política com o pertencimento e a defesa dos interesses da classe trabalhadora. Nesse sentido, a consciência crítica pode conduzir a/o profissional tanto a uma consciência de classe quanto a uma visão fatalista que provoca o imobilismo e o descrédito na possibilidade de transformação social que tem, como telos de seu Projeto Societário, a emancipação humana. 
Tal visão fatalista deve-se à sensação de inferioridade da/do profissional face à monstruosidade e perversidade da lógica do capital. Assim, a/o assistente social se vê incapaz, podendo ser colocada(o) em uma situação de isolamento, o que fragiliza sua consciência crítica e atuação coerente com a consciência de classe, voltando-se para projetos individuais (tais como a exoneração) como uma forma de defesa.

A materialização do Projeto Ético-Político no cotidiano profissional requer o reconhecimento dos elementos concretos, teóricos, políticos e de luta pelos quais as/os profissionais vivenciam. Assim, somente a formação de uma consciência crítica diante da realidade (direcionamento proposto pelas diretrizes curriculares) por si só não garante um profissional comprometido, podendo até gerar um sujeito competente teoricamente, mas tendente ao imobilismo, diante de tantos limites reais.

Não queremos afirmar que a crítica paralisa a ação, pois entendemos a crítica como um movente: o próprio movimento da história demonstra que é a contradição, a negação da afirmação, que possibilita o movimento de superação/transformação.

A dimensão de classe social, o reconhecimento de pertencimento à mesma, é mediado pela formação de uma consciência classista eesta, por sua vez, está ligada a vivências e experiências reais e concretas. Daí, a partir de leituras sobre a temática, observações e realização de entrevistas junto aos profissionais, buscamos captar os elementos que dizem respeito à participação política e organizativa, tanto no próprio trabalho como no decorrer de sua vida, a partir de uma concepção de mundo que se distancia da perspectiva da própria história como destino e se aproxima de uma perspectiva de sujeito, cujas escolhas definem sua trajetória pessoal e coletiva na sociedade. 


\section{tempordilis}

SILVA, S. de S.; MUSTAFÁ, M. A. da S. M. PROJETO ÉTICO-POLÍTICO

\section{O MOVIMENTO DA CONSCIÊNCIA DE CLASSE}

O tema consciência de classe é objeto de inúmeras polêmicas no pensamento sociológico e filosófico de tradição marxista. Em determinado momento histórico, algumas dessas correntes analisavam a referida categoria fazendo uma associação direta à constituição de uma vanguarda revolucionária - o partido (LENIN, 2010). Tal debate compreendia esse instrumento político como mediação concreta entre a atual situação e a futura sociedade socialista (LUKÁCS, 2003). Entretanto, esse debate precisa ser atualizado à luz das experiências históricas mundiais pósrevolucionárias, pois diante de tais determinações é impossível manter esse mesmo entendimento (MÉSZÁROS, 2009).

Dessa forma, a tradição marxista e marxiana, com a qual compartilhamos, nos traz a necessidade de sempre tomar o real como ponto de partida para análise. Marx e Engels (1998, p.20) buscam compreender a formação da consciência do ser humano a partir da vida histórica e socialmente construída. Dessa forma, "[...] não é a consciência que determina a vida, mas sim a vida que determina a consciência", pois:

São os homens que produzem suas representações, suas idéias, etc.,mas os homens reais, atuantes, tais como são condicionados por um determinado desenvolvimento de suas forças produtivas e das relações que a elas correspondem, inclusive as mais amplas formas que estas podem tomar. A consciência nunca pode ser mais que o ser consciente; e o ser dos homens é o seu processo de vida real (MARX; ENGELS, 1998, p.19). 
Lukács (1970, p.3) argumenta que o trabalho, enquanto categoria fundante do ser social, secoloca como um momento essencial para a constituição desse ser, não somente pela construção de produtos, mas pela formação da própria consciência. Esta, enquanto produto tardio do desenvolvimento do ser material, não é jamais um produto de menor valor ontológico: “Quando se diz que a consciência reflete a realidade e, sob essa base, torna possível intervir nessa realidade para modificá-la, quer-se dizer que a consciência tem um real poder no plano do ser e não que ela é carente de força".

Em sua última obra considerada a mais madura, Prolegômenos para uma ontologia do ser social, Lukács (2010) trabalha exaustivamente essa temática, privilegiando a dimensão teleológica do trabalho, e, para tanto, busca em Marx (1985,p. 211-212) os fundamentos da atividade que constitui a centralidade da práxis humana, na medida em que, ao transformar a natureza, o homem transforma a si mesmo, desenvolve as suas potencialidades adormecidas, assim como aquelas do meio circundante e as coloca sob o seu domínio e submete à sua vontade. Para uma melhor compreensão da teleologia do trabalho, vejamos a citação de Marx à qual nos referimos acima:

Pressupomos o trabalho como forma exclusivamente humana. Uma aranha executa operações semelhantes às do tecelão, e a abelha supera mais de um arquiteto ao construir sua colméia. Mas o que distingue o pior arquiteto da melhor abelha é que ele figura na mente sua construção antes de transformála em realidade. No fim do processo do trabalho aparece um resultado que já existia antes idealmente na imaginação do trabalhador. Ele não transforma apenas o material sobre o qual opera; ele imprime ao material o projeto que tinha conscientemente em 


\section{temporalis}

SILVA, S. de S.; MUSTAFÁ, M. A. da S. M. PROJETO ÉTICO-POLÍTICO

mira, o qual constitui a lei determinante do seu modo de operar e ao qual tem de subordinar sua vontade.

Nesse sentido, o trabalho pode servir de modelo para compreender as outras posições socioteleológicas, incluindo-se aí as projeções de transformação das relações materiais e espirituais que fundamentam uma ordem social - através, especialmente do que se denomina de projetos societários - exatamente porque, quanto ao ser, ele é a forma originária. O fato simples de que no trabalho se realiza uma posição teleológica é uma experiência elementar da vida cotidiana de todos os homens, tornando-se isso um componente ineliminável de qualquer pensamento, desde os discursos cotidianos até a economia e a filosofia.

Assim, dadas as condições materiais em que estão inseridas(os), as/os assistentes sociaistendem a ter sua subjetividade afetada pelo fetiche e alienação presentes nas relações sociais capitalistas. No entanto, através das palavras de Marx e Engels (1998) de que "[...] o educador precisa ser educado [...]" em processo de formação de uma consciência de classe, vale ressaltar que a formação profissional com a disseminação da direção hegemônica da profissão, associada à luta concreta da categoria, devem se constituir como fundamentos centrais para tomada de uma nova consciência.

Compreendemos que a consciência de classe não se encontra materializada, necessariamente, em um determinado instrumento organizativo construído pela classe, como sindicatos ou partidos, por exemplo. Nem muito menos se manifesta na ação puramente individual, mas no movimento contraditório de transição da dimensão meramente particular/individual ao reconhecimento enquanto pertencente ao gênero humano. 
Daí afirmarmos ser a consciência de classe um movimento contraditório de constante afirmação, negação e superação da classe, não um produto feito e acabado. Assim, esse movimento não se dá de forma imediata, mas passa por diversas mediações e fases.

Sendo a consciência a internalização de certas relações sociais vividas pelos indivíduos, a inserção destes em novas relações sociais tende a possibilitar novas internalizações. Assim, o movimento da consciência nada mais é senão a expressão da própria contradição da realidade (IASI, 2006). Em nosso entendimento, a formação da consciência pressupõe não apenas a constatação da contradição da realidade, mas a sua superação.

Acompanhando a trajetória dessas(es) trabalhadoras(es) da assistência social, percebemos um forte movimento de organização e posicionamento político visando tanto à defesa, à conquista e à ampliação de seus direitos trabalhistas quantoà melhor efetivação da política da assistência social no município. Algumas posturas fatalistas e individualistas, no entanto, não deixaram de ser evidenciadas.

A pauta trabalhista (isonomia, melhores condições de trabalho, aumento salarial, etc.) trazida pelas(os) trabalhadoras(es) da assistência social de Recife constitui um elemento que aglutina as diferentes categorias, objetivando uma direção comum. Sob o processo de constituição e tomada de consciência por parte da classe trabalhadora ao enfrentamento do capital, Marx (2009b) sinalizava para os determinantes materiais de reprodução dessa classe.

As condições econômicas, inicialmente, transformaram a massa do país em trabalhadores. A dominação do capital criou para essa massa uma situação comum, interesses comuns. Essa massa, 


\section{temporalis}

SILVA, S. de S.; MUSTAFÁ, M. A. da S. M. PROJETO ÉTICO-POLÍTICO

pois, é já, face ao capital, uma classe, mas ainda não o é para si mesma. Na luta, [...] essa mesma se reúne, se constitui em classe para si mesma (MARX, 2009b, p. 190).

A partir de observações junto a esse movimento, destacamos como importante espaço de reivindicação política as assembleias e greves, que ocorreram entre os anos de 2008 a 2010, impulsionadas pelo Sindicato dos Servidores Municipais do Recife (SINDSEPRE). Todo primeiro semestre do ano o sindicato chama todas(os) as/os servidores da PCR para discutir principalmente o reajuste salarial, pois é nesse período que a prefeitura envia à Câmara de vereadores um projeto de lei com proposta de reajuste salarial.

Por não concordar com a direção do SINDSEPRE, filiado à Central Única dos Trabalhadores (CUT), que demonstrou descaso com a Política da Assistência Social e postura de cooptação de suas lideranças, as/os trabalhadores da SAS/IASC começaram a formar suas próprias assembleias, a fim de construir sua pauta de negociações, para agregá-la à pauta maior das/dos servidoras(es) municipais.

Nesse movimento, em 2009, as/os servidoras(es) SAS/IASC elegem uma comissão composta pelos diferentes segmentos profissionais para levar a pauta construída coletivamente nas assembleias setoriaisà prefeitura, nas mesas de negociações setoriais da assistência na PCR, juntamente ao sindicato ${ }^{19}$.

\footnotetext{
${ }^{19}$ Vale ressaltar que a PCR afirma negociar somente com sindicatos (pessoas jurídicas) e não com pessoas físicas. Dessa forma, as/os servidoras(es) mesmo não concordando com posturas e práticas do sindicato, construíram uma relação de proximidade, mantendo uma autonomia.
} 


\section{temporalis}

SILVA, S. de S.; MUSTAFÁ, M. A. da S. M. PROJETO ÉTICO-POLÍTICO

Dessa forma, as/os trabalhadoras(es) foram aprendendo a negociar e a construir espaços coletivos a fim de defender politicamente seus direitos e a própria política de que fazem parte. Todo esse movimento se deu a partir dos espaços já existentes (equipes técnicas, reuniões centrais, assembleias gerais, etc..) e a construção de novos espaços, como principal exemplo temos as assembleias setoriais e a formação da comissão de servidoras(es). Tal processo se evidenciou mediante crítica e postura política desses sujeitos.

Os elementos que evidenciamos anteriormente apontam para grandes modificações no plano organizativo e subjetivo da classe trabalhadora. As organizações sindicais construídas, em especial o PT, sofrem com rebaixamento programático e políticos de suas propostas, o que tem impulsionado a construção de novas alternativas políticas.

Tomando as observações e entrevistas realizadas com algumas assistentes sociais dos CRASs de Recife, vemos que existe o reconhecimento de pertencimento a um grupo, aproximando-se da consciência reivindicatória e sindical (DURIGUETTO; MONTANO, 2010). Esse processo de identificação entre diferentes sujeitos pode, em certa medida, contribuir tanto para compartilhar indignações, como para a formação de uma solidariedade de classe, elemento essencial à tomada de consciência classista. Nas palavras de Marx (1985) toda "[...] solidariedade entre os empregados e desempregados [...]" perturba a ação livre da lei geral do capital.

Um exemplo de solidariedade desse grupo se deu nas negociações na greve de 2010, no momento as/os servidoras(es) pautavam a isonomia,equiparação para todo o nívelsuperior e proporcionalidade com o nível médio, a PCR ofereceu um aumento de $24 \%$ apenas para o nível superior, que posteriormente transformou-se em 


\section{tempordilis}

SILVA, S. de S.; MUSTAFÁ, M. A. da S. M. PROJETO ÉTICO-POLÍTICO

gratificação sobre o salário. Considerando que sua pauta não fora atendida, o grupo (nível superior) optou por dividir sua gratificação com o nível médio afim de atender ao critério de proporcionalidade ${ }^{20}$.

Vemos,aqui, uma demonstração concreta de um processo de tomada de decisão a partir de escolhas pautadas em princípios de dignidade e solidariedade, fato que levou o grupo a contrariar a proposta sugerida pela PCR em função da salvaguarda das motivações/reivindicações (proporcionalidade e isonomia) da greve, o que nos permite concluir que a luta política, pautada na defesa de princípios ético-políticos, mesmo que diante da hegemonia ideológica do capital, tende a possibilitar a formação de sujeitos políticos e conscientes que atuam e transformam o real, dentro das limitações do mesmo.

\section{CONSIDERAÇÕES FINAIS}

A partir da análise de documentos sobre a Política de Assistência Social (leis, regulamentos e planos), sua implementação no município de Recife (Plano de Assistência Social, Plano Plurianual, etc.) e entrevistas aos assistentes sociais dos CRAS do município tornou-se evidente a precarização e incompletude da efetivação dessa política.

É a partir dessas vivências e experiência reais e concretas de pauperização, tanto da política municipal de Assistência Social como das relações trabalhistas, que as/os trabalhadoras(es) da assistência social (dentre esses assistentes sociais) encontram-se em processo de construção de um movimento de luta pela garantia

\footnotetext{
${ }^{20}$ Lembramos que tal decisão foi deliberada em assembléia setorial e não foi unânime entre as/ostrabalhadoras(es) da SAS/IASC presentes.
}

Temporalis, Brasilia (DF), ano 11, n.21, p.177-209, jan./jun. 2011. 


\section{temporalis}

SILVA, S. de S.; MUSTAFÁ, M. A. da S. M. PROJETO ÉTICO-POLÍTICO

de seus direitos trabalhistas como também pela garantia do direito da classe trabalhadora à consolidação da Política de Assistência, tal como foi idealizada com seus devidos mecanismos de regulamentação.

Nossas reflexões sobre o real nos fizeram perceber que o Projeto Ético-Político do Serviço Social, por sua clara vinculação a um Projeto Societário socialista, leva para o âmbito da práxis no exercício profissional daquelas(es) com ele comprometidos, um forte viés classista. Tal direcionamento, por sua vez, tende a ser assimilado e a estimular as/os profissionais de outras categorias, pois, no momento da crise e conflito de consciência gerado pela contradição entre relações trabalhistas e a execução e regulação da Política da Assistência Social no âmbito municipal, a figura do outro assume uma grande importância para formação de uma nova consciência.

A consciência crítica das/dos assistentes sociais, adquirida tanto durante a formação acadêmica, pautada nos princípios da direção hegemônica do Projeto Ético-Político, quanto a partir de sua participação em organizações e movimentos políticos (Movimento Estudantil de Serviço Social - MESS, organizações ligados à Igreja Católica, organizações sindicais da categoria, partidos políticos, dentre outros), éum importante elemento para uma tomada de consciência de classe. Logo, a consciência crítica constitui-se em uma mediação para o processo de uma efetiva consciência de classe.

Dessa forma, por possuir um viés classista, o Projeto Ético-Político contribui para a formação da consciência de classe não só das/dos assistentes sociais como também de outros profissionais. Por outro lado, o projeto profissional do Serviço Social também é fruto da tomada de consciência classista da categoria junto às lutas sociais da classe trabalhadora, haja vista sua inserção no processo 


\section{tempordilis}

SILVA, S. de S.; MUSTAFÁ, M. A. da S. M. PROJETO ÉTICO-POLÍTICO

de luta pela redemocratização do país e, posteriormente, pela consolidação dos direitos sociais, através da regulamentação da Política de Assistência Social.

Estamos assim diante de uma relação dialética entre o Projeto Ético-Político, a formação da consciência de classe e um Projeto Societário, pois este contribuiu para constituição daquele que, por sua vez, incorpora e ao mesmo tempo supera a própria dimensão da profissão, apontando para a construção de outra sociabilidade.

Essa pesquisa não se realizou apenas com o objetivo de atender as exigências acadêmicas do Mestrado, mas também tem como intuito fortalecer concretamente a formação de uma consciência de classe junto às/aos trabalhadoras(es) da assistência social no movimento do real, fato que vem se verificando a partir da socialização de seus resultados e análises em palestras, reuniões com segmentos da categoria mobilizada de outros espaços profissionais, e no âmbito da própria formação em Serviço Social no Curso de Graduação e Pós-Graduação da UFPE.

Esperamos com essas reflexões contribuir para a produção de conhecimento em Serviço Social no tocante ao debate sobre o PEP, a consciência de classe e projeto societário, especialmente para a interlocução da relação teoria-prática. Os elementos aqui analisados podem servir também de motivação para futuras pesquisas, especialmente no que se refere àatuação da gestão do PT e sua articulação com o capital internacional e com as lideranças dos movimentos sindicais e sociais, particularmente no que se refere àconsolidação de direitos adquiridos e hoje ameaçados, tais como aqueles veiculados para a população mais pauperizada através da Política de Assistência Social. 


\section{temporalis}

SILVA, S. de S.; MUSTAFÁ, M. A. da S. M. PROJETO ÉTICO-POLÍTICO

\section{REFERÊNCIAS}

ARAÚJO, C. C.; LIMA, V. F. S. de A.; SILVA, M. O. da S. Implantação, implementação e condições de funcionamento do SUAS nos municípios. In: COUTO, B. R.; RAICHELIS, R.; YAZBEK, M. C.O Sistema Único de Assistência Social no Brasil: uma realidade em movimento. São Paulo: Cortez, 2010.

BEHRING, E. Brasil em contra-reforma: desestruturação do Estado e perda de dirietos. São Paulo: Cortez, 2003.

BRASIL. Secretaria Nacional de Assistência Social. Metas e estratégias - Plano /decenal SUAS Plano 10 (Metas e Estratégias deliberadas nas Conferencias Nacionais e Metas Governo Federal). [2007]. Disponível em: <http://www.mds.gov.br/cnas/metas-eestrategias-plano-decenal/metas-e-estrategias-plano-decenal>.

BRASIL. Secretaria Nacional de Assistência Social. Política Nacional de Assistência Social PNAS/2004 [e] Norma Operacional Básica NOB/SUAS. Brasília, nov. 2005. Disponível em: <http://www.mds.gov.br/gestaodainformacao/biblioteca/secretaria -nacional-de-assistencia-social-snas/cadernos/politica-nacional-deassistencia-social-2013-pnas-2004-e-norma-operacional-basica-deservico-social-2013-nobsuas>.

BRASIL. Secretaria Nacional de Assistência Social.Sistema Único de Assistência Social - SUAS: Norma Operacional Básica de Recursos Humanos do SUAS: NOB-RH/SUAS. Brasília, dez. 2006. Disponível em:<http://www.mds.gov.br/assistenciasocial/protecaobasica/servi cos/protecao-e-atendimento-integral-a-familia-paif/arquivos/normaoperacional-de-rh-suas.pdf/view $>$. 


\section{tempordilis}

SILVA, S. de S.; MUSTAFÁ, M. A. da S. M. PROJETO ÉTICO-POLÍTICO

CONSELHO FEDERAL DE SERVIÇO SOCIAL (Brasil). Assistentes Sociais no Brasil: elementos para o estudo do perfil profissional. Brasília: CFESS, 2005. Disponível em: <http://www.cfess.org.br/arquivos/perfilas_edicaovirtual2006.pdf.

COUTO, Berenice Rojas; RAICHELIS, Raquel; YAZBEK, Maria Carmelita. A Política Nacional de Assistência Social e o SUAS: apresentando e problematizando fundamentos e conceitos. In:COUTO, B. R.; RAICHELIS, R.; YAZBEK, M. C.O Sistema Único de Assistência Social no Brasil: uma realidade em Movimento. São Paulo: Cortez, 2010.

DURIGUETTO, Maria Lúcia; MONTANO, Carlos. Estado, Classe e Movimento Social. São Paulo: Cortez, 2010.(Biblioteca Básica.Serviço Social).

IAMAMOTO, M. V. Serviço Social em tempo de capital fetiche: capital financeiro, trabalho e questão social. 2. ed. São Paulo: Cortez, 2008.

IAMAMOTO, Marilda Villela; CARVALHO, Raul de. Relações Sociais e Serviço Social no Brasil: esboço de uma interpretação históricometodológica. 15. ed. São Paulo: Cortez, 2003.

IASI, M. L. As metamorfoses da consciência de classe: o PT entre a negação e o consentimento. São Paulo: Expressão Popular, 2006.

LENIN, V.I. Que fazer?Problemas candentes do nosso movimento. São Paulo: Expressão Popular, 2010.

LUKÁCS, G. As bases ontológicas do pensamento e da atividade do homem. 1970. Disponível em: <http://www.esnips.com/doc.asbases-ontologicas-dopensamento-e-da-atividade-do-homem>. Acesso em: 22 nov. 2010.

Temporalis, Brasilia (DF), ano 11, n.21, p.177-209, jan./jun. 2011. 
SILVA, S. de S.; MUSTAFÁ, M. A. da S. M. PROJETO ÉTICO-POLÍTICO

.História e Consciência de Classe: estudos sobre a dialética marxista. São Paulo: Martins Fontes, 2003.

. Prolegômenos para uma ontologia do ser social. Questões de princípios para uma ontologia hoje tornada possível. São Paulo: Boitempo, 2010.

MARX, K.; ENGELS, F. A ideologia Alemã. São Paulo: Martins Fontes, 1998.

. Para a questão judaica. São Paulo: Expressão Popular, $2009 a$.

- Miséria da Filosofia: resposta à Filosofia da Miséria, do Sr. Proudhon. São Paulo: Expressão Popular, 2009b.

. O Capital: crítica da economia política. 2. ed. São Paulo: Nova Cultura, 1985.

. Manuscritos econômico-filosóficos. São Paulo: Boitempo, 2004.

MÉSZÁROS, I. Para além do capital. São Paulo: Boitempo, 2009.

MUSTAFÁ, M. A. da S. M. Ação católica operária: fé e luta em tempos difíceis no nordeste do Brasil. 1992. Dissertação (mestrado) Programa de Pós-Graduação em Serviço Social, Universidade Federal de Pernambuco.

OLIVEIRA, F. de. Crítica à razão dualista/O ornitorrinco. São Paulo: Boitempo, 2003. 


\section{temporolis}

SILVA, S. de S.; MUSTAFÁ, M. A. da S. M. PROJETO ÉTICO-POLÍTICO

RECIFE (PE). Secretaria de Assistência Social. Plano Municipal de Assistência Social 2007-2015. Recife, 20 jul. 2007.Impresso.

. Prefeitura. Lei Orgânica do município do Recife. Recife,4 abr. 1990.

RAWLS, J. Uma teoria da Justiça. São Paulo: Martins Fontes, 1997.

SALVADOR, E. Fundo Público e Seguridade Social no Brasil. São Paulo: Cortez, 2010.

SPOSATI, A. de O. Assistência na trajetória das políticas sociais: uma questão em análise. 10. ed. São Paulo: Cortez, 2008.

TRABALHAR na Assistência social em defesa dos direitos de Seguridade Social: contribuições do Conjunto CFESS/CRESS ao debate sobre definição de Trabalhadores de Assistência Social. Brasília: CFESS/CRESS, 2010. Versão preliminar. Disponível em: <http://www.cfess.org.br/arquivos/cartilhacfesscress_seguridade_ site.pdf $>$. Acesso em: 31 jan. 2011. 
